\title{
Characteristic properties of ceramic membrane derived from fly ash with different loadings and sintering temperature
}

\author{
Siti Nur Afiqah Zulkifli, Azeman Mustafa ${ }^{\star}$, Mohd Hafiz Dzarfan Othman, Siti Khadijah Hubadillah \\ Advanced Membrane Technology Research Centre (AMTEC), Faculty of Chemical and Energy Engineering, Universiti Teknologi Malaysia, 81310 \\ Johor, Johor Bharu, Malaysia
}

* Corresponding author: r-azeman@utm.my

Article history

Received 5 May 2018

Revised 1 June 2018

Accepted 2 July 2018

Published Online 25 June 2019

\begin{abstract}
Nowadays, ceramic membrane developed from wastes has gained attention, especially towards water separation applications. With abundant and high silica content of fly ash, low cost ceramic membrane was successfully prepared via phase inversion and sintering technique. Prior to both phase inversion and sintering process, ceramic suspension was prepared at different loadings, ranging from $40 \mathrm{wt} \%$ to $50 \mathrm{wt} \%$ fly ash and subsequently sintered at temperature ranging from $1150^{\circ} \mathrm{C}$ to $1350^{\circ} \mathrm{C}$. By varying fly ash content and sintering temperature, the morphology, mechanical strength and phase transformation characteristics of the prepared membrane were affected. The characterisation of prepared membrane were investigated by using scanning electron microscopy, three-point bending test, and X-ray diffraction (XRD). The mechanical strength of the membrane increased with increasing fly ash loading (up to $45 \%$ ), however too much fly ash loading resulted in decrease of its mechanical strength probably due the presence of unburnt at higher fly ash contents. This unburnt carbon contributed to the vacant space during sintering process and had the tendency to increase formation of pores, simultaneously reduced its mechanical strength. In addition, the SEM results also illustrated a cross-sectional image of the membrane which had become more elastic with increasing fly ash loading and denser as sintering temperature gradually increased. In addition, increasing the fly ash loading likely discouraged the formation of desired finger-like structure. The XRD results however showed continuous presence of mullite with the increasing sintering temperature which contributed higher mechanical strength. The preliminary performance tests indicated that the optimum conditions to produce hollow fibre ceramic membrane from fly ash were at $45 \mathrm{wt} \%$ fly ash loading sintered at $1350^{\circ} \mathrm{C}$ and has a pure water flux of $131 \mathrm{~L} / \mathrm{m}^{2} \mathrm{~h}$.
\end{abstract}

Keywords: Fly ash, hollow fibre ceramic membrane, different loading, sintering temperature

\section{INTRODUCTION}

Development of ceramic membrane in water filtration technology has gained a lot of attention from both science community and research realm on waste water treatment. This is due to numerous excellent properties possessed by ceramic membranes, such as high mechanical strength and the ability to perform in harsh condition; and it is deemed to be more productive compared to commercialised polymer membrane. However, ceramic membrane has an economical drawback given its higher cost, specifically ceramic material sources (alumina, titania and zirconia). Nowadays, there are ample literatures reported on the development of low cost ceramic membrane, using inexpensive material towards water separation application, few being rice husk ash (Hubadillah et al., 2017), kaolin (Harun et al., 2014; Hubadillah et al., 2017), bauxite (Wang et al., 2015) and fly ash (Dong et al., 2008).

Fly ash is a waste in a form of greyish fine powder, is abrasive and have alkaline characteristics (Yao et al., 2015). It can be attained through various mediums: 1) combustion of incinerator, 2) municipal solid waste treatment and 3) electric power plant, via combustion and pulverised coal within processing (Vassilev et al., 2004). Coals that had been grinded or pulverised were used as a source of combustion in the boiler's chamber, which then produce coarse ash particles known as bottom ash, fallen to the bottom of the combustion chamber. As for fly ash, a lighter fine ash, it is either trapped or collected by particulate emission control devices, such as electrostatic precipitators or filter fabric bag houses, before it is released out to ambient air to avoid any air pollution (Brigden \& Santillo, 2002). Despite so, improper management of the abundant fly ash waste can cause water pollution (Zhipeng et al., 2015; Jiang et al., 2007). Fly ash is one of the alternatives that has potential to be used as a base material for ceramic material, due to the presence of high silica content. Thus, it has been widely utilised in various applications such as in construction, an adsorbent for removal of organic compounds, heavy metals, dyes and zeolite synthesis. This adds high value to fly ash, especially with its contribution in reducing environmental pollution (Ahmaruzzaman, 2010). In suit, this present study proposes fabrication of hollow fibre ceramic membrane with lower cost, with reference to fly ash material.

Fabrication of ceramic membrane using fly ash via heat treatment method allows vitrification process for glass formation to avoid any leaching of toxicity of fly ash where all metals and radioactive substances are embedded in a metal matrix. Vitrification is a technological treatment upon hazardous materials including fly ash, spent catalyst, radioactive waste, spent batteries, and electroplating sludge to avoid any leaching toxicity. Report that, the process contributes to three major advantages. First, it can immobilize heavy metals and transform hazardous metals into stabilised slag. Second, its 
higher temperature will decompose and burn off the organic toxics such as PCDD/Fs, PBDE or PAHs. Third, it accumulates all useful metals in the products as recoverable forms. Lastly, the verification glass can be used safely in various applications (Carabin \& Gagnon, 2007; Kuo et al., 2012; Maken et al., 2005; Tian et al., 2012).

Other than that, higher amount of $\mathrm{Si}$ and $\mathrm{Al}$ elements are present in fly ash, a vital characteristic in producing ceramic membrane (Haiying et al., 2010; Nordin et al., 2016; Zhang et al., 2016). Importantly, these elements can generate formation of glass ceramic system, specifically when the membrane is sintered at higher temperature (mullite, anorthite and cordierite), which then contributed to higher resistance of chemical and thermal reactivity with good mechanical strength (Dong et al., 2011; Liu et al., 2016; Wei et al., 2016). Prior to this, there were also studies on the fabrication of fly ash membrane employing slip casting method (Fang et al., 2013, Jedidi et al., 2009)), cylindrical pellets (Liu et al., 2016), pressing method (Suresh et al., 2016) and few others.

The present study aimed to fabricate fly ash hollow fibre membrane using phase inversion technique as to our knowledge it has never been carried out before. Phase inversion technique is chosen not only for its simplicity and versatility, but also the capability to produce porous membrane with desired morphology once phase inversion had occurred (van Rijn \& Nijdam, 2004). In one single step, various morphology of membranes can be made to be either porous or dense, only in below or upper layer, or even both. The effects of fly ash content and sintering temperature will be investigated and characterised in terms of morphology, mechanical strength and phase transformation by using scanning electron microscopy, 3-point bending test and X-ray diffraction (XRD).

Table 1 Preparation of fly ash suspension in different loadings.

\begin{tabular}{lllll}
\hline F.A loading & $\mathbf{4 0 \%}$ & $\mathbf{4 5 \%}$ & $\mathbf{4 7 . 5 \%}$ & $\mathbf{5 0 \%}$ \\
\hline Fly ash & $40 \mathrm{~g}$ & $45 \mathrm{~g}$ & $47.5 \mathrm{~g}$ & $50 \mathrm{~g}$ \\
NMP & $54 \mathrm{~g}$ & $48.4 \mathrm{~g}$ & $45.6 \mathrm{~g}$ & $42.8 \mathrm{~g}$ \\
PESf & $5 \mathrm{~g}$ & $5.6 \mathrm{~g}$ & $5.9 \mathrm{~g}$ & $6.25 \mathrm{~g}$ \\
Arlacel & $1 \mathrm{~g}$ & $1 \mathrm{~g}$ & $1 \mathrm{~g}$ & $1 \mathrm{~g}$ \\
\hline
\end{tabular}

\section{EXPERIMENTAL}

\section{Materials}

Fly ash was collected from Kapar Energy Ventures Stesen Janaelektrik Sultan Salahuddin Abdul Aziz, Selangor Darul Ehsan, to which later sieved to below $36 \mu \mathrm{m}$. In order to make sure the ceramic particles in the suspension are well dispersed and have completed phase inversion during spinning process, polyethersulfone (PESf) (Radel A300, Ameco Performance, USA) was used as a polymer binder, while Arlacel P135 (Polyethyleneglycol 30 Dipolyhydroxystrearate, CRODA) as a dispersant agent, inclusive N-methylpyrrolidone (NMP, QRëC ${ }^{\mathrm{TM}}$ ) - all combined to make a solvent for the ceramic suspension.

\section{Preparation of ceramic suspension}

In this research, the ceramic suspension for fabrication of hollow fibre ceramic membrane was prepared in four different loadings, which were $40 \%, 45 \%, 47.5 \%$ and $50 \%$, as shown in Table 1 . Initially, PESf was at first dried for 30 minutes to eliminate humidity, whereas Arlacel P135 gel was melted in an oven at $60{ }^{\circ} \mathrm{C}$ for a day. Arlacel P135 was stirred in NMP until dissolved, and fly ash powder and PESf were then added to the solution. For this study, the ratio of ceramic particle to polymer binder was fixed at 8:1 (fly ash:PESf), as presented in Table 1. Next, the suspensions were milled for 5 days in an alumina jar with four agate mill balls of $10 \mathrm{~mm}$ in size and one $20 \mathrm{~mm}$ agate mill ball. The planetary ball mill (Model: NQM-2, Magna) was set at constant rate of $182 \mathrm{rpm}$ to ensure ceramic particles, solvent, and additives were wellmixed. Though prior to the spinning process, the ceramic suspension was degassed under vacuum for about one hour, or until no air bubbles was seen in the suspension.

\section{Fabrication of ceramic membrane}

The spinning process was executed by extruding ceramic suspension through a single tube orifice spinneret. The hollow fibre precursors were spun in spinneret set up through a tube in orifice, whereby its outer/inner diameter is at $2.4 / 1.2 \mathrm{~mm}$. It was loaded into coagulant bath at extrusion rates of $8 \mathrm{~mL} / \mathrm{min}$, bore fluid rate at $10 \mathrm{~mL} / \mathrm{min}$, with an air gap between spinneret and coagulant bath kept at $5 \mathrm{~cm}$. The fabricated hollow fibre precursors were immersed in water bath for at least 24 hours. Then, they were dried at room temperature. After fly ash membrane was successfully fabricated in different loadings, it was then sintered at different temperature points $\left(1150^{\circ} \mathrm{C}\right.$, $1250^{\circ} \mathrm{C}$ and $1350^{\circ} \mathrm{C}$ ) inside a tubular furnace (XY-1700). The membranes were finally ready for characterisations.

\section{CHARACTERISATION}

\section{Chemical composition analysis}

$\mathrm{X}$-ray fluorescence test was carried out to determine the presence of elements in raw material fly ash that may contribute to the formation of crystallization and mullitization throughout sintering process at high temperature. As for the $100 \mathrm{~g}$ fly ash powder with particle size $<36 \mu \mathrm{m}$, it was tested with an XRF spectrometer (XRF-1800, Shimadzu Corporation, Japan).

\section{Viscosity}

Viscosity of the suspended solution at different fly ash loadings was recorded immediately prior to the spinning process by using Brookfield DV II + Pro Viscometer (model LVDV-II + P) at shear rate $55 \mathrm{~s}^{-1}$ at room temperature.

\section{Scanning electron microscope analyses}

Membrane morphologies are a crucial factor that affect membrane's performance. Thus why SEM testing on the membrane surface morphologies was conducted. SEM micrographs of both crosssections of the hollow fibre membranes were taken at varying magnifications. Samples for cross - sectional SEM were prepared by cutting the hollow fibre at ambient temperature without any pretreatment, but it was necessary to confirm that the sample had a clean cut of its cross-sectional fracture. The samples were then placed on the metal holder, before being sputter-coated with gold under vacuum for 3 min.

\section{X-ray diffraction}

XRD analysis was conducted to recognise the phase transformation behaviour of the membrane after being sintered. The recognition phase is vital because it can prove both physical and mechanical properties. $45 \%$ fly ash loading of hollow fibre ceramic membrane at three different sintered temperatures was finely grinded using mortar and pestle into fine particle, then investigated with XRD instrument at $2 \theta$ values within the range of $1^{\circ}-80^{\circ}$. The instrument was operated at $0.05^{\circ} \mathrm{s}$ scanning rate, $40 \mathrm{kV}, 40 \mathrm{~mA}$ and $\mathrm{Cu} \mathrm{K \alpha}(\lambda=$ $0.154506 \mathrm{~nm}$ ) radiation. In the end, the XRD result showed a formation of amorphous and crystalline phases that was present in $45 \%$ fly ash hollow ceramic membrane, sintered at different sintering temperatures $\left(1150{ }^{\circ} \mathrm{C}, 1250^{\circ} \mathrm{C}\right.$ and $\left.1350^{\circ} \mathrm{C}\right)$.

\section{Three point bending}

The importance of three-point bending test is to determine the mechanical strength of fly ash hollow ceramic membrane. The measurement was taken by Instron Model 5544 that provided a load cell for $1 \mathrm{kN}$. The test was carried out by putting the hollow fly ash sample onto the sample holder of $43 \mathrm{~mm}$ in length. For the bending strength, $\sigma F$ was calculated according to the following equation. Both outer and inner diameters were measured with a caliper:

$$
. \sigma_{\mathrm{F}}=\frac{8 \mathrm{FLD} \mathrm{D}_{\mathrm{o}}}{\pi\left(\mathrm{D}_{0}^{4}-\mathrm{D}_{\mathrm{i}}^{4}\right)} \sigma_{\mathrm{F}}=8 \cdot \mathrm{F} \cdot \mathrm{L} \cdot \mathrm{D}_{\mathrm{o}} / \pi\left(\mathrm{D}_{0}^{4}-\mathrm{D}_{\mathrm{i}}^{4}\right)
$$

where $\mathrm{F}$ indicates the maximum load required for fracture to occur $(\mathrm{N})$, $\mathrm{L}$ as the length of hollow fibre (HF) membrane $(\mathrm{mm}), \mathrm{D}_{\mathrm{o}}$ as the outer 
diameter of hollow fibre (HF) membrane $(\mathrm{mm})$ and $\mathrm{D}_{\mathrm{i}}$ as the inner diameter of HF membrane (mm).

\section{Water flux}

Permeation performance was measured from the pure water flux by filtering deionised water through the membrane until a stable permeate flux was obtained. The water flux was calculated by using:

$$
L_{p}=\text { Q/A.t.P }
$$

where $L_{p}$ is indicated as the water's permeability (L/h.m ${ }^{2}$.bar), $Q$ as the volume of water permeated through membrane (L), A as the membrane's surface area $\left(\mathrm{m}^{2}\right), \mathrm{t}$ as the sampling time $(\mathrm{h})$ and $\mathrm{P}$ as the transmembrane pressure (bar)

\section{RESULTS AND DISCUSSION}

\section{Fly ash composition}

Table 2 shows the chemical composition of the fly ash. Based on the table, the fly ash was majorly consisted of alumina and silica, whereas the other impurities were $\mathrm{MgO}, \mathrm{CaO}, \mathrm{Fe}_{2} \mathrm{O}_{3}$ and $\mathrm{TiO}_{2}$. The produced chemical properties of fly ash are generally depending on the type of coal burnt and techniques used in handling and their storage (Bartoňová, 2015). This is the reason why fly ash was difficult to identify its general characteristic, mostly due to the different types of classes, the presence of chemical substances and different combustion process that produces fly ash. Even if it is difficult to make general statements regarding the properties of fly ashes, ASTM international 2015 has classified fly ash into two classes which are class F and C, based on the presence of chemical substances in fly ash (Myadraboina et al.,2017). As fly ash has higher of silica content, it is classified to be in Class F, meanwhile, the one with higher of calcium content will be in Class C. Physical, mineralogical and chemical properties of fly ash will strongly affect its performance. From the XRF result, since it was discovered to have $77 \%$ silica content, it was decided that the fly ash material in the present study to be in Class $\mathrm{F}$.

Table 2 Chemical composition in fly ash.

\begin{tabular}{ccccccc}
\hline Element & $\mathrm{SiO}_{2}$ & $\mathrm{Al}_{2} \mathrm{O}_{3}$ & $\mathrm{CaO}$ & $\mathrm{MgO}$ & $\mathrm{Fe}_{2} \mathrm{O}_{3}$ & $\mathrm{TiO}_{2}$ \\
\hline & $77 \%$ & $16 \%$ & $1.6 \%$ & $0.48 \%$ & $3.6 \%$ & $0.91 \%$ \\
\hline
\end{tabular}

\section{Viscosity of fly ash dope suspension}

Figure 1 presents the viscosity of four fly ash loadings for fabrication of hollow fibre ceramic membrane at shear rate of $55 \mathrm{~s}^{-1}$. Fly ash contains unburnt carbon and requires pre-treatment to remove them to minimum level (Maroto-Valer et al., 2005; Uçurum et al., 2011). Indirectly, with the increase of fly ash loading, it contributes to the increasing unburnt carbon content. Simultaneously increased the viscosity of ceramic suspended, these unburnt carbons trapping the oxide compound and contributing vacant space in the membrane when sintered at higher temperature, hence producing less dense membrane. Other than that, it is also indicated (Kingsbury \& Li, 2009; Li et al., 2015; Wang \& Lai, 2012) that higher viscosity does not support phase inversion process between non-solvent and solvent. This is because when it is above the critical level of suspension viscosity, the fingerlike phenomenon is not observed and likely to form a sponge-like structure instead. Though it is also stated by (Hubadillah et al., 2016) in their study that in higher ceramic loading, the finger like voids in morphology structure tend to be shorter and diminish. As in the present study, at $1150^{\circ} \mathrm{C}$ sintering temperature for $40 \%, 45 \%$ and $47.5 \%$ fly ash loading showed a porous structure with large macrovoids on the inner surface and sponge-like regions on the outer surface of hollow membranes. The differences between the cross section of 50\% fly ash loading and the formation of spongy structure in the morphology, also known as symmetric morphology and porous membrane are described in Figure 2. Meanwhile, from the viscosity of $40 \%$ and $45 \%$ fly ash loading, the present study could suggest that the optimum viscosity for fly ash suspension in fabricating hollow fibre membrane with desired asymmetric structures was within the average of $142 \mathrm{cp}$.

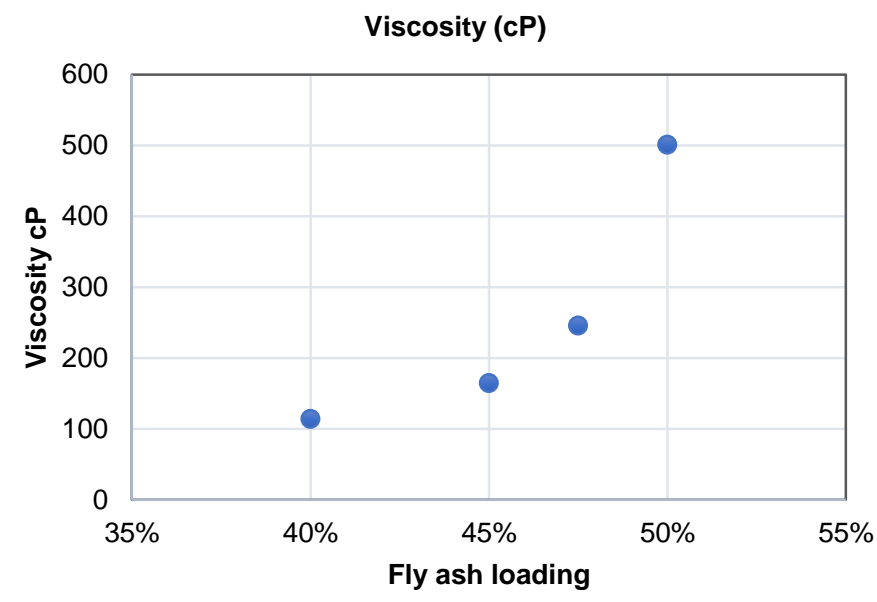

Figure 1: Viscosity graph over $55 \mathrm{~s}^{-1}$ shear rate.

\section{Morphology fly ash hollow fibre membrane}

Membrane morphology plays a significant role in the stability of the membrane. Figure 2 has shown the cross-section image of four different hollow fibre ceramic membrane loadings in different sintering temperature. Generally, phase inversion is a technique to produce asymmetrical structure with the finger-like and sponge-like regions on cross section of the membrane (Abdullah et al., 2016; Kingsbury \& Li, 2009). It is formed during the process of spinning, when the hollow fibre precursor is extruded vertically downwards into the coagulation bath. The exchanges of solvent and non-solvent occurred in ceramic membrane led to a change of the suspended ceramic membrane, from the state of thermodynamically stable to unstable. The unstable state creates an asymmetric morphology of the membrane. It changes from one phase solution into two phases, which are called a) ceramic rich phase, forming a solid matrix of the membrane and b) ceramic poor phase, forming membrane pores or macrovoids (Baker, 2012).

However, most membranes in present study can achieve asymmetric morphology structure, besides the 50\% fly ash loading at $1150^{\circ} \mathrm{C}$ sintering temperature which just observed the presence of spongy region. Meanwhile, the morphology structure of $40 \%$ to $47.5 \%$ fly ash loading, is in the agreement with the study of (Hubadillah et al., 2016) on the formation of asymmetric membrane (van Rijn \& Nijdam, 2004). At sintering temperature of $1150^{\circ} \mathrm{C}$, the morphology structure was an accumulation of fly ash particle, still within the process of grain growth and not fully nucleated to each other. In fact, the form of the membrane is really porous. This suggests that the sintering temperature for fly ash hollow fibres should be higher than $1150^{\circ} \mathrm{C}$; otherwise the accumulated fly ash grain would not be growing and in neck for coalescence, and thus the resultant hollow fibre would be too weak in mechanical strength, hardly to be handled.

The growth of grain was found to be effectively suppressed in increasing temperature. As we can observe from Figure 2, at sintering $1250^{\circ} \mathrm{C}$, the fly ash grains started to form a neck, increasing the size of pores from small finger-like voids to large macrovoids, surrounded by the growth grain, then forming sponge-like structure to the cross section of membrane morphology. Meanwhile, at sintering temperature of $1350^{\circ} \mathrm{C}$, the outer layer was not present during separation phase. All the grains were already coalescence to one another, therefore no pores can be formed. Meanwhile, the inner layer was present during the separation phase with its large macrovoids. Thus, it is proved that the phase inversion method can construct a good membrane with suitable macrovoids ( $\mathrm{Li}, 2007)$. Aside from that, we can also indicate that, with the increased sintering temperature, the grain growth of particles tends to nucleate to each other and form compact surface such as the morphology for sintering temperature at $1350^{\circ} \mathrm{C}$. The increased sintering temperature makes the morphology of membrane become denser, similar to another study on the stainless steel hollow fibre membrane by (Li et al., 2015). As discussed by (Benes et al., 2000) the 
sintering temperature is set to obtain sufficient strength from the formation of necks without significant grain growth and shrinkage. Other than that, PESF binding agent also contributes to the formation of macrovoids when it is burnt off at higher sintering temperature (Abdullah et al., 2016).

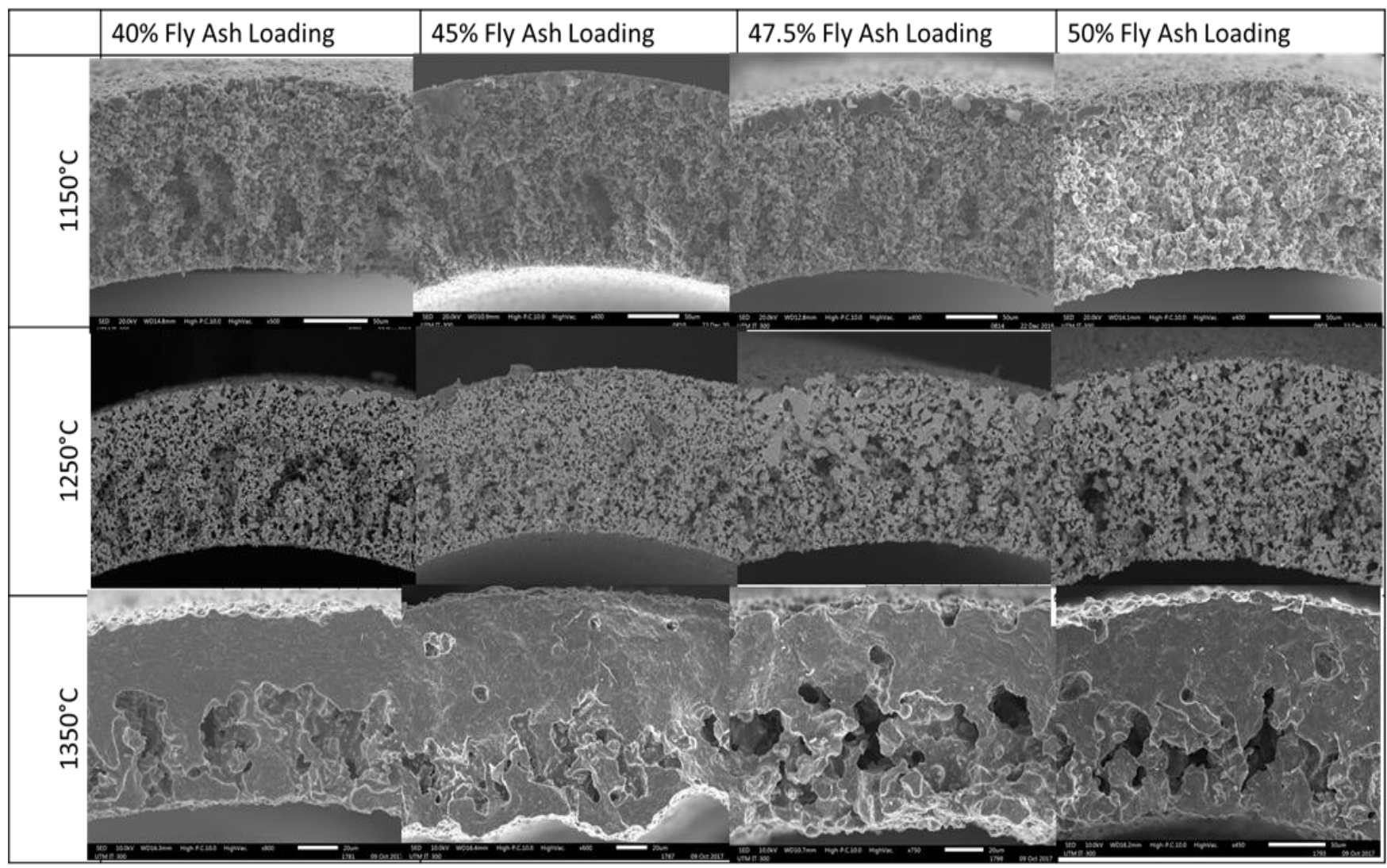

Figure 2 Scanning electron microscopy images of ceramic membrane prepared from fly ash.

\section{Crystal structure of fly ash hollow fibre}

Figure 3 depicts XRD patterns of four different samples of which one was $45 \%$ of non-sintered fly ash hollow fibre and the other four were $45 \%$ fly ash hollow fibre that were sintered at $1150^{\circ} \mathrm{C}, 1250^{\circ} \mathrm{C}$ and $1350^{\circ} \mathrm{C}$. An observation on the peaks and trends from the XRD patterns convey during the major dominating phase, both mullite $\left(2 \mathrm{Al}_{2} \mathrm{O}_{3} \cdot \mathrm{SiO}_{2}\right)$ and Dmisteinbergite, a hexagonal polymorph of anorthite are present $\left(\mathrm{CaAl}_{2} \mathrm{Si}_{2} \mathrm{O}_{8}\right)$. Apart from these, antrigote $\left(3 \mathrm{MgO}_{2} \cdot \mathrm{SiO}_{2} .2 \mathrm{H}_{2} \mathrm{O}\right)$ was also present in small quantities, while Pyrophyllite $\left(\mathrm{Al}_{2} \mathrm{O}_{3} .4 \mathrm{SiO}_{2} \cdot \mathrm{H}_{2} \mathrm{O}\right)$ was in higher intensity. The ceramic glass system such as mullite and Dmisteinbergite offered desired properties such as high mechanical strength and good chemical resistances for the production of fly ash ceramic membrane (Liu et al., 2016).

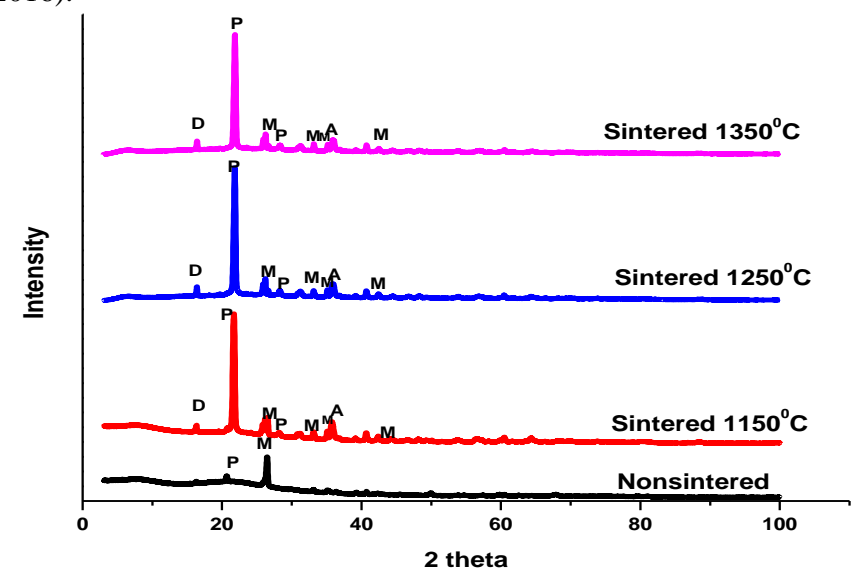

Figure 3 XRD graph for non-sintered fly ash hollow fibre ceramic membrane followed by sintered membrane at temperature $1150^{\circ} \mathrm{C}$, $1250^{\circ} \mathrm{C}$, and $1350^{\circ} \mathrm{C}$.
Supported by the study of Wang et al. (2014), $\mathrm{MgO}-\mathrm{Al}_{2} \mathrm{O}_{3}-\mathrm{SiO}_{2}$ system coal fly ash glass-ceramics have an outstanding properties, few being an elevated thermal stability, good chemical resistances and very low thermal expansion coefficient (Nettleship, 1996). $\mathrm{CaO}-\mathrm{Al}_{2} \mathrm{O}_{3}-$ $\mathrm{SiO}_{2}$ system glass-ceramics contribute high mechanical strength, excellent dimensional stability, and abrasion, inclusive corrosion resistance. All these properties benefit fly ash to its capability to be used in high temperature or high thermal shock resistance. Based on the comparison of XRD patterns of different sintering temperature, it indicates an occurrence of continuous phase transformations during the sintering process. Correlated to the result of mechanical strength, the bending strength increased as the sintering temperature increased.

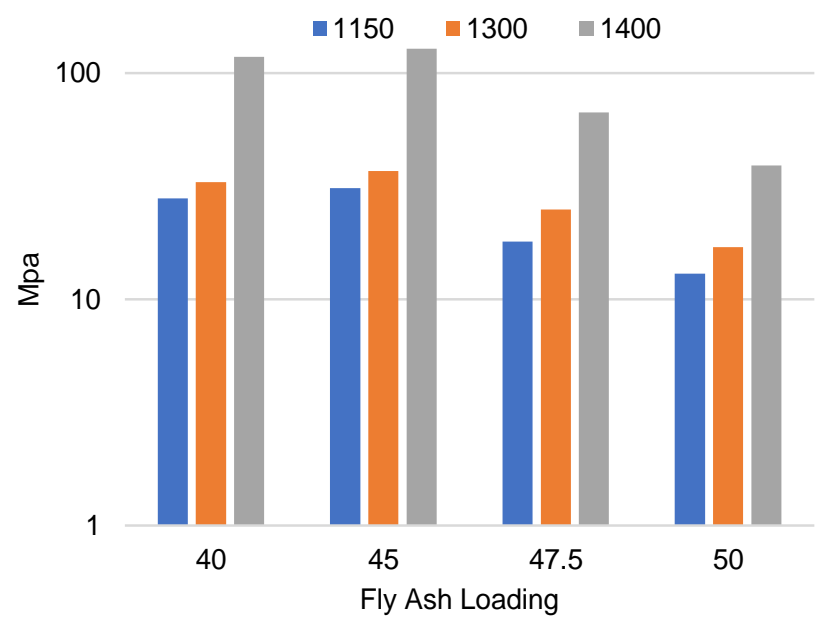

Figure 4 The mechanical strength of different sintering temperature and different loadings. 


\section{Mechanical strength}

Figure 4 illustrates the mechanical strength of the prepared ceramic membrane based on fly ash at different loadings and different sintering temperatures. Such result is in agreement with (Hubadillah $e t$ al., 2016; Li et al., 2015) whereby higher sintering temperature contributed to higher mechanical strength. The results showed that when the membranes were fabricated with $40 \mathrm{wt} \%$, $45 \mathrm{wt} \%, 47.5 \mathrm{wt} \%$ and $50 \mathrm{wt} \%$ fly ash loadings, the bending strength of the membrane were recorded at $28 \mathrm{MPa}, 31 \mathrm{MPa}, 18 \mathrm{MPa}$ and $13 \mathrm{MPa}$ at sintering temperature of $1150^{\circ} \mathrm{C}$ and $33 \mathrm{MPa}, 37 \mathrm{MPa}, 25 \mathrm{MPa}$ and $17 \mathrm{MPa}$ of $1250^{\circ} \mathrm{C}$ respectively. Lastly, at sintering temperature of $1350^{\circ} \mathrm{C}$, once again there was an increase of mechanical strength for each loading from $40 \%$ to $50 \%$, which are at $118 \mathrm{Mpa}, 128 \mathrm{Mpa}, 67 \mathrm{Mpa}$ and $39 \mathrm{Mpa}$. This is mainly due to the formation of neck, given the increased sintering temperature will slowly eliminate the significant grain growth or shrinkage, thus contributes to the sufficient strength to the membrane (Carter \& Norton, 2013).

However, in view of the loading, the bending strength of fly ash ceramic membranes is a contradictory result when compared to other studies on ceramic membrane, to which it is generally known that when ceramic loading is increased, the mechanical strength should likewise increase (Hubadillah et al., 2016). This study instead discovered that the mechanical strength had increased as the fly ash loading increased from $40 \%$ to $45 \%$, however decreased further at $47.5 \%$ and $50 \%$ fly ash loadings. It is presumable that this could be due to the presence of unburnt carbon (Bartoňová, 2015; Zhao et al., 2016). With the increase of loading and unburnt carbon content of the fly ash, the latter of the two could contribute to the formation of vacant space to the membrane when sintered at higher temperature. It also appeared to be more porous for ceramic membrane with higher loading, in which inflicted from the high amount of unburnt carbon content. Besides that, from a previous study, the presence of unburnt carbon in fly ash given benefit when it was used as a pore forming agent in fabricating porous membrane (Shao et al., 2009). (Zhang et al., 2015), studied the vitrified slag (VS) with the addition of 10, 20 and 30 wt.\% Oil Shale Fly Ash (OSFA). The values of sintering shrinkage, density and compressive strength decreased with the increase of OSFA content, indicating that the increasing dosages of oil shale fly ash resulted in an increasing temperature of liquid phase formation, and thus hindered the densification of sintering body. Wei et al. (2016) also described that liquid glassy phase promotes the higher sinterability and resulted in formation of large pore diameter. Thus, it is really important for them to determine the optimum fly ash content to act as pore forming. This is because, aside from having to achieve the porous membrane, a good mechanical strength is also important for the quality of membrane Similarly, with this present study, even the study does not use fly ash as a pore forming agent, but as a main ceramic material instead. Determining the optimum fly ash loading in fabricating hollow fibre ceramic membrane is really important, before the carbon in fly ash gives drawback to the fly ash membrane.

\section{Water Flux}

Since the $45 \%$ fly ash membrane gave a high result in regards to the bending strength, compared to other loadings in all sintering temperature, then the $45 \%$ fly ash membrane had arranged for the water flux performances. Figure 5 demonstrates the result of water flux in 1 bar pressure for applying the $45 \%$ fly ash loading, that had been sintered in different temperature. The result of water flux was different to the general conceptual of ceramic membrane, in which with increased sintering temperature, the water flux should be decreased. However, the result of present study was not in sequential pattern. At $1150^{\circ} \mathrm{C}$, the $45 \%$ fly ash hollow ceramic membrane performed with $478 \mathrm{~L} / \mathrm{m}^{2} . \mathrm{hr}$, followed by $1250^{\circ} \mathrm{C}$ with $51 \mathrm{~L} / \mathrm{m}^{2}$.hr and $1350^{\circ} \mathrm{C}$ with $131 \mathrm{~L} / \mathrm{m}^{2} . \mathrm{hr}$. The non-sequential result can be related to the inner layer of cross section of SEM image in Figure 6, whereby the morphology structure of fly ash at $1250^{\circ} \mathrm{C}$ had higher resistance of water flux compared to $1150^{\circ} \mathrm{C}$ and $1350^{\circ} \mathrm{C}$, due to its block of grain and spongy structure. Meanwhile, for the fly ash membrane at sintering temperature of $1150^{\circ} \mathrm{C}$, large macrovoids were in its morphology contributed to the increased of water flux. Same goes to $1350^{\circ} \mathrm{C}$, even the outer layer of the morphology membrane at $1350^{\circ} \mathrm{C}$ was dense and compact, which only small pores to be observed. Though large macrovoids were still present on the inner, causing an increase of water flux.

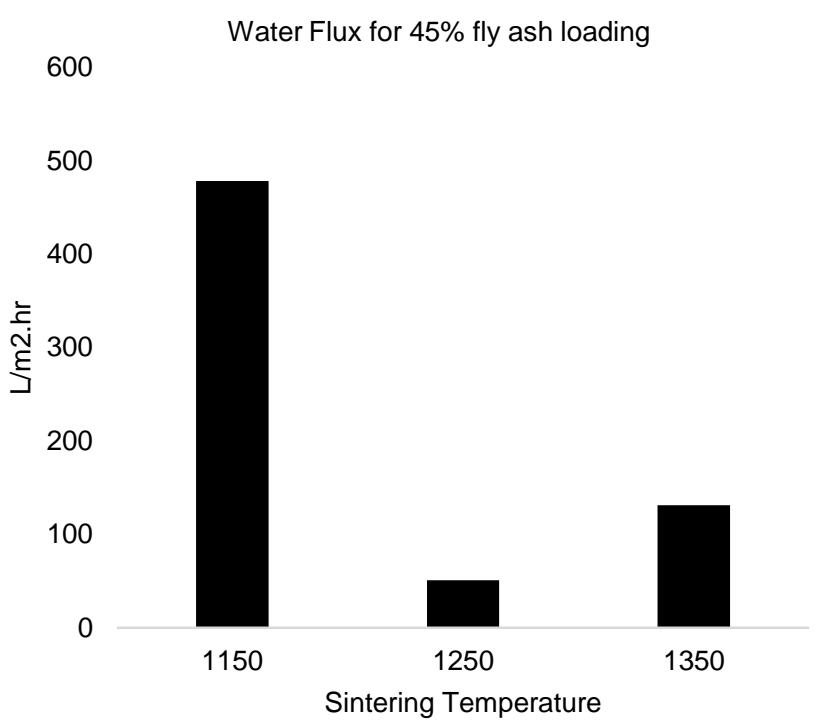

Figure 5 Water flux for $45 \%$ fly ash hollow ceramic membrane in different sintering temperature.

As the high result from water flux permeation test, it is determined that the $45 \%$ loading for fly ash hollow ceramic membrane at $1350^{\circ} \mathrm{C}$ could be categorised as microfiltration membrane. From previous studies, microfiltration membrane is applicable to decolourisation of dye (Doke \& Yadav, 2016; Jedidi et al., 2011) . (Qin et al., 2015) also used microfiltration of fly ash ceramic membrane for clarification of kiwi fruit juice, (Suresh et al., 2016) along microfiltration ceramic membrane for oil water emulsion treatment. Thus, the best ceramic hollow fibre membrane of $45 \%$ fly ash loading at $1350^{\circ} \mathrm{C}$ could be applied in treating of colloidal suspension.

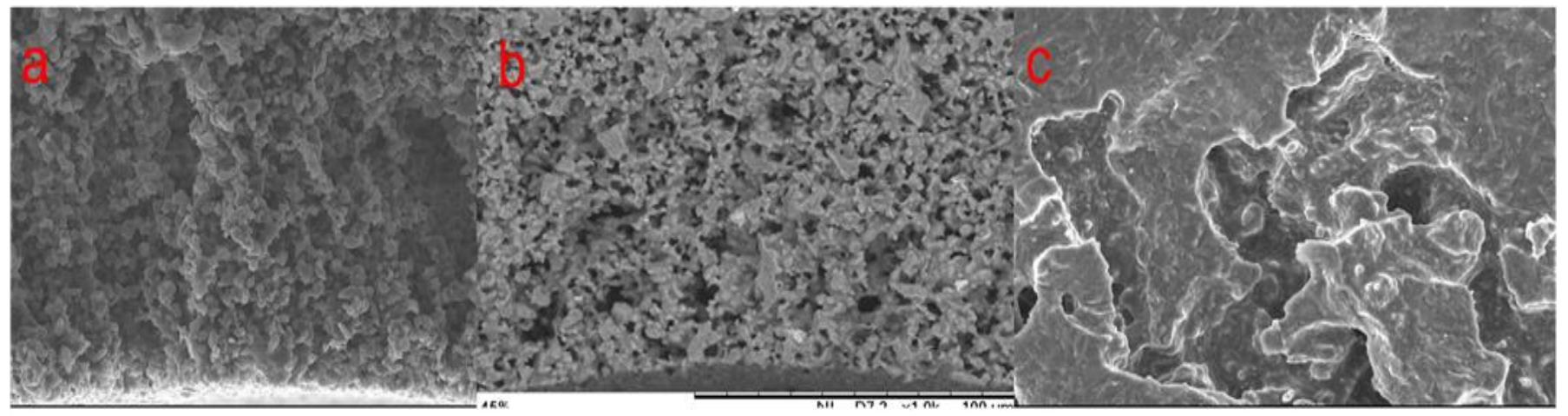

Figure 6 The cross-section image of inner layer of $45 \%$ fly ash loading a temperature a) $1150^{\circ} \mathrm{C}$ b) $1250^{\circ}$ and C) $1350^{\circ} \mathrm{C}$. 


\section{CONCLUSION}

In conclusion, by considering the loading of ceramic membrane, the best loading was at $45 \%$ fly ash hollow membrane, to which performed a high mechanical strength in each different sintering temperature of $1150^{\circ} \mathrm{C}, 1250^{\circ} \mathrm{C}$, and $1350^{\circ} \mathrm{C}$ and performed very well in water flux result. It is to determine the optimum loading, because the presence of unburnt carbon in fly ash gives drawback to the fabricated fly ash membrane when sintered at high temperature by making a vacant space or forming pores on the membrane. However, from the three sintering temperature, at $1350^{\circ} \mathrm{C}$, this degree can give a good result. Other than that, it is also suggested to treat the fly ash before utilising it in the ceramic membrane to burn off all the presence of carbon.

\section{ACKNOWLEDGEMENT}

The authors appreciate the financial support for this research from the Ministry of Higher Education Malaysia by the Universiti Teknologi Malaysia under the Higher Institution Centre of Excellence Scheme (Project Number: R.J090301.7846.4J205).

\section{REFERENCES}

Abdullah, N., Rahman, M. A., Othman, M. H. D., Ismail, A. F., Jaafar, J., \& Aziz, A. A. (2016). Preparation and characterization of self-cleaning alumina hollow fiber membrane using the phase inversion and sintering technique. Ceramics International, 42(10), 12312-12322. https://doi.org/10.1016/j.ceramint.2016.05.003

Ahmaruzzaman, M. (2010). A review on the utilization of fly ash. Progress in Energy and Combustion Science, 36(3), 327-363. https://doi.org/10.1016/j.pecs.2009.11.003

Baker, R. W. (2012). Membrane Technology and Applications (Third Edit). A John Wiley \& Sons, Ltd.

Bartoňová, L. (2015). Unburned carbon from coal combustion ash: An overview. Fuel Processing Technology, 134, 136-158. https://doi.org/10.1016/j.fuproc.2015.01.028

Benes, N., Nijmeijer, A., \& Verweij, H. (2000). Microporous silica membranes. Membrane Science and Technology (Vol. 6). Elsevier Masson SAS. https://doi.org/10.1016/S09275193(00)80015-7

Brigden, K., \& Santillo, D. (2002). Heavy metal and metalloid content of fly ash collected from the Sual, Mauban and Masinloc coal-fired power plants in the Philippines, 2002. Greenpeace Research Laboratories, Department of Biological Sciences,University of Exeter, Exeter, UK. Technical Note: 07/2002. Retrieved from http://www.greenpeace.to/publications/ philflyash.pdf

Carabin, P., \& Gagnon, J.-R. (2007). Plasma gasification and vitrification of ashconversion of ash into glass-like products and syngas. World of Coal Ash (WOCA), May 7-10, 2007, Covington, Kentucky, USA, 1-11.

Carter, C. B., \& Norton, M. G. (2013). Sintering and Grain Growth. In: Ceramic Materials. Springer, New York, pp. 439-456. doi:10.1007/978-1-46143523-5_24

Cho, H., Oh, D., \& Kim, K. (2005). A study on removal characteristics of heavy metals from aqueous solution by fly ash. Journal of Hazard Material, 127(1-3), 187-195. doi:10.1016/j.jhazmat.2005.07.019

Dong, Y., Feng, X., Feng, X., Ding, Y., Liu, X., \& Meng, G. (2008). Preparation of low-cost mullite ceramics from natural bauxite and industrial waste fly ash. Journal of Alloys and Compounds, 460(1-2), 599-606. doi:http://dx.doi.org/10.1016/j.jallcom.2007.06.023

Dong, Y., Hampshire, S., Zhou, J. er, Ji, Z., Wang, J., \& Meng, G. (2011) Sintering and characterization of flyash-based mullite with $\mathrm{MgO}$ addition. Journal of the European Ceramic Society, 31(5), 687-695. https://doi.org/10.1016/j.jeurceramsoc.2010.12.012

Doke, S. M., \& Yadav, G. D. (2016). Synthesis of novel titania membrane support via combustion synthesis route and its application in decolorization of aqueous effluent using microfiltration. Clean Technologies and Environmental Policy, 18(1), 139-149. doi:10.1007/s10098-015-1000-3

Fang, J., Qin, G., Wei, W., Zhao, X., \& Jiang, L. (2013). Elaboration of new ceramic membrane from spherical fly ash for microfiltration of rigid particle suspension and oil-in-water emulsion. Desalination, 311, 113126. https://doi.org/10.1016/j.desal.2012.11.008

Ghasemi Torkabad, M., Keshtkar, A.R. and Safdari, S.J. (2017) Comparison of polyethersulfone and polyamide nanofiltration membranes for uranium removal from aqueous solution. Progress in Nuclear Energy 94, 93-100.

Haiying, Z., Youcai, Z., \& Jingyu, Q. (2010). Characterization of heavy metals in fly ash from municipal solid waste incinerators in Shanghai. Process Safety and Environmental Protection, 88(2), 114-124. https://doi.org/10.1016/j.psep.2010.01.001

Harun, Z., Hubadillah, S. K., Hasan, S., \& Yunos, M. Z. (2014). Effect of thermodynamic properties on porosity of ceramic membrane prepared by phase inversion. Applied Mechanics and Materials, 575, 31-35. doi:104028/ www.scientific.net/AMM.575.31

Hubadillah, S. K., Harun, Z., Othman, M. H. D., Ismail, A. F., \& Gani, P. (2016) Effect of kaolin particle size and loading on the characteristics of kaolin ceramic support prepared via phase inversion technique. Journal of Asian Ceramic Societies, 4(2), 164-177. https://doi.org/10.1016/j.jascer. 2016.02.002

Hubadillah, S. K., Harun, Z., Othman, M. H. D., Ismail, A. F., Salleh, W. N. W., Basri, H., Yunos, M. Z. and Gani, P. (2016) Preparation and characterization of low cost porous ceramic membrane support from kaolin using phase inversion/sintering technique for gas separation: Effect of kaolin content and non-solvent coagulant bath. Chemical Engineering Research and Design, 112, 24-35.

Hubadillah, S. K., Othman, M. H. D., Harun, Z., Ismail, A. F., Rahman, M. A. and Jaafar, J. (2017a) A novel green ceramic hollow fiber membrane (CHFM) derived from rice husk ash as combined adsorbent-separator for efficient heavy metals removal. Ceramics International 43(5), 4716-4720.

Hubadillah, S. K., Othman, M. H. D., Harun, Z., Ismail, A. F., Rahman, M. A. Jaafar, J., Jamil, S. M. and Mohtor, N. H. (2017b) Superhydrophilic, low cost kaolin-based hollow fibre membranes for efficient oily-wastewater separation. Materials Letters, 191, 119-122.

Jedidi, I., Khemakhem, S., Larbot, A., \& Ben Amar, R. (2009). Elaboration and characterisation of fly ash based mineral supports for microfiltration and ultrafiltration membranes. Ceramics International, 35(7), 2747-2753. https://doi.org/10.1016/j.ceramint.2009.03.021

Jedidi, I., Khemakhem, S., Saïdi, S., Larbot, A., Elloumi-Ammar, N., Fourati, A., Charfi, A., Salah, A.B. and Amar, R.B. (2011) Preparation of a new ceramic microfiltration membrane from mineral coal fly ash: Application to the treatment of the textile dying effluents. Powder Technology, 208(2), 427-432.

Jiang, J. guo, Xu, X., Wang, J., Yang, S. jian, \& Zhang, Y. (2007). Investigation of basic properties of fly ash from urban waste incinerators in China. Journal of Environmental Sciences, 19(4), 458-463. https://doi.org/ 10.1016/S1001-0742(07)60076-X

Kingsbury, B. F. K., \& Li, K. (2009). A morphological study of ceramic hollow fibre membranes. Journal of Membrane Science, 328(1-2), 134-140. https://doi.org/10.1016/j.memsci.2008.11.050

Kuo, Y. M., Huang, K. L., \& Lin, C. (2012). Metal behavior during vitrification of municipal solid waste incinerator fly ash. Aerosol and Air Quality Research, 12(6), 1379-1385. https://doi.org/10.4209/aaqr.2011.12.0231

Li, K. (2007). Ceramic Membrane for Separation and Reaction. John Wiley \& Sons Ltd.

Liu, J., Dong, Y., Dong, X., Hampshire, S., Zhu, L., Zhu, Z., \& Li, L. (2016). Feasible recycling of industrial waste coal fly ash for preparation of anorthite-cordierite based porous ceramic membrane supports with addition of dolomite. Journal of the European Ceramic Society, 36(4), 1059-1071. https://doi.org/10.1016/j.jeurceramsoc.2015.11.012

Maken, S., Jang, S. H., Park, J. W., Song, H. C., Lee, S., \& Chang, E. H. (2005) Vitrification MSWI fly ash using Brown's gas and fate of heavy metals. Journal of Scientific and Industrial Research, 64(3), 198-204.

Maroto-Valer, M. M., Zhang, Y., Granite, E. J., Tang, Z., \& Pennline, H. W. (2005). Effect of porous structure and surface functionality on the mercury capacity of a fly ash carbon and its activated sample. Fuel, 84(1), 105-108. doi:10.1016/j.fuel.2004.07.005

Myadraboina, H., Setunge, S., \& Patnaikuni, I. (2017). Pozzolanic Index and lime requirement of low calcium fly ashes in high volume fly ash mortar. Construction and Building Materials, 131, 690-695. https://doi.org/ 10.1016/j.conbuildmat.2016.11.038

Nettleship, I. (1996). Applications of porous ceramics. Key Engineering Materials, 122-124, 305-324. https://doi.org/10.4028/www.scientific.net/ KEM.122-124.305

Nordin, N., Abdullah, M. M. A. B., Tahir, M. F. M., Sandu, A. V., \& Hussin, K. (2016). Utilization of fly ash waste as construction material. International Journal of Conservation Science, 7(1), 161-166. Retrieved from http://search.ebscohost.com/login.aspx?direct=true \&db=vth\&AN=11343 08\& lang=es\&site $=$ ehost-live

Qin, G., Lü, X., Wei, W., Li, J., Cui, R., \& Hu, S. (2015). Microfiltration of kiwifruit juice and fouling mechanism using fly-ash-based ceramic membranes. Food and Bioproducts Processing, 96, 278-284. doi:10.1016/j.fbp.2015.09.006

Shao, Y., Jia, D., \& Liu, B. (2009). Characterization of porous silicon nitride ceramics by pressureless sintering using fly ash cenosphere as a poreforming agent. Journal of the European Ceramic Society, 29(8), 15291534. https://doi.org/10.1016/j.jeurceramsoc.2008.09.012 
Suresh, K., Pugazhenthi, G., \& Uppaluri, R. (2016). Fly ash based ceramic microfiltration membranes for oil-water emulsion treatment: Parametric optimization using response surface methodology. Journal of Water Process Engineering, 13, 27-43. https://doi.org/10.1016/j.jwpe. 2016.07.008

Tian, S., Li, J., Liu, F., Guan, J., Dong, L., \& Wang, Q. (2012). Behavior of Heavy Metals in the Vitrification of MSWI Fly Ash with a Pilot-scale Diesel Oil Furnace. Procedia Environmental Sciences, 16, 214-221. https://doi.org/10.1016/j.proenv.2012.10.030

Uçurum, M., Toraman, Ö. Y., Depci, T., \& Yoğurtçuoğlu, E. (2011). A Study on Characterization and Use of Flotation to Separate Unburned Carbon in Bottom Ash from Çayirhan Power Plant. Energy Sources, Part A: Recovery, Utilization, and Environmental Effects, 33(6), 562-574. doi: $10.1080 / 15567030903117638$

van Rijn, C. J. M., \& Nijdam, W. (2004). Overview membrane technology. In Membrane Science and Technology (Vol. 10, pp. 1-23). https://doi.org/ 10.1016/S0927-5193(04)80018-4

Vassilev, S. V., Menendez, R., Diaz-Somoano, M., \& Martinez-Tarazona, M. R. (2004). Phase-mineral and chemical composition of coal fly ashes as a basis for their multicomponent utilization. 2. Characterization of ceramic cenosphere and salt concentrates. Fuel, 83(4-5), 585-603. https://doi.org/10.1016/j.fuel.2003.10.003

Wang, B., \& Lai, Z. (2012). Finger-like voids induced by viscous fingering during phase inversion of alumina/PES/NMP suspensions. Journal of Membrane Science, 405-406, 275-283. https://doi.org/10.1016/ j.memsci.2012.03.020

Wang, F., Ye, J., He, G., Liu, G., Xie, Z., \& Li, J. (2015). Preparation and characterization of porous $\mathrm{MgAl}_{2} \mathrm{O}_{4}$ spinel ceramic supports from bauxite and magnesite. Ceramics International, 41(6), 7374-7380. doi:http://dx.doi.org/10.1016/j.ceramint.2015.02.044

Wang, S., Zhang, C., \& Chen, J. (2014). Utilization of coal fly ash for the production of glass-ceramics with unique performances: A brief review. Journal of Materials Science and Technology, 30(12), 1208-1212. https://doi.org/10.1016/j.jmst.2014.10.005

Wei, Z., Hou, J., \& Zhu, Z. (2016). High-aluminum fly ash recycling for fabrication of cost-effective ceramic membrane supports. Journal of Alloys and Compounds, 683, 474-480. https://doi.org/10.1016/j.jallcom. 2016.05.088

Yao, Z. T., Ji, X. S., Sarker, P. K., Tang, J. H., Ge, L. Q., Xia, M. S., \& Xi, Y. Q. (2015). A comprehensive review on the applications of coal fly ash. Earth-Science Reviews, 141, 105-121. https://doi.org/http://dx.doi.org/ 10.1016/j.earscirev.2014.11.016

Zhang, X., Devanadera, M. C., Roddick, F. A., Fan, L. and Dalida, M. L. (2016) Impact of algal organic matter released from Microcystis aeruginosa and Chlorella sp. on the fouling of a ceramic microfiltration membrane. Water Resources 103, 391-400.

Zhang, Z., Li, A., Wang, X., \& Zhang, L. (2016). Stabilization/solidification of municipal solid waste incineration fly ash via co-sintering with wastederived vitrified amorphous slag. Waste Management, 56, 238-245. https://doi.org/10.1016/j.wasman.2016.07.002

Zhang, Z., Zhang, L. and Li, A. (2015) Development of a sintering process for recycling oil shale fly ash and municipal solid waste incineration bottom ash into glass ceramic composite. Waste Management 38, 185-193.

Zhao, S., Duan, Y., Liu, M., Wang, C., Zhou, Q., \& Lu, J. (2016). Effects on enrichment characteristics of trace elements in fly ash by adding halide salts into the coal during CFB combustion. Journal of the Energy Institute. https://doi.org/10.1016/j.joei.2016.12.003

Zhipeng, T., Bingru, Z., Chengjun, H., Rongzhi, T., Huangpu, Z., \& Fengting, L. (2015). The physiochemical properties and heavy metal pollution of fly ash from municipal solid waste incineration. Process Safety and Environmental Protection, 98, 333-341. https://doi.org/10.1016/ j.psep.2015.09.007 